\title{
Effects of Inhibitors of Nucleic Acid and Protein Synthesis on Ethyl Methanesulfonate-Induced Sister Chromatid Exchanges in Chinese Hamster Cells
}

\author{
Akira Sono* and Kengo Sakaguchi** \\ *Research Laboratories, Toyo Jozo Co. Ltd., Ohito-cho, Tagata-gun, Shizuoka- \\ ken, Japan, and **Department of Biology, University of California, San Diego, \\ California, U.S.A.
}

\begin{abstract}
DNA synthesis inhibitors enhanced and protein synthesis inhibitors reduced the frequency of sister chromatid exchanges induced by the alkylating agent, ethyl methanesulfonate in Chinese hamster cells. The synergism and antagonism mainly occured when cells were exposed to these agents during the first half of the $\mathrm{S}$ phase.
\end{abstract}

Our purpose was to examine the effects of various inhibitors of nucleic acid and protein synthesis on ethyl methanesulfonate (EMS)-induced sister chromatid exchange (SCE) frequency in Chinese hamster cells. Although there are many studies on the SCE-inducing ability of mutagenic agents such as alkylating chemicals, interaction between the alkylating agent and other kinds of inhibitors on SCE frequency have not been studied except for caffeine. Such studies could be important for detecting the potential synergistic actions of two mutagenic agents on mutagenesis and carcinogenesis.

Results of our investigation of the combined effects of EMS and a number of inhibitors on SCE formation are reported here. Several combinations displayed either synergism or antagonism.

\section{MATERIALS AND METHODS}

Cultures of Chinese hamster fibroblasts (clone DON D-6) were the generous gift of Dr. Kato of the National Institute of Genetics, Mishima, Japan. The cells were grown in stationary cultures at $37^{\circ} \mathrm{C}$ with Eagle's minimal essential medium supplemented with $10 \%$ fetal calf serum (GIBCO, heat-inactivated at $56^{\circ} \mathrm{C}, 30 \mathrm{~min}$ ), nonessential amino acid, penicillin and streptomycin. The duration in hours of the phases of the cell cycle in this medium containing $10^{-5} \mathrm{M}$ BrdU was: $\mathrm{G}_{1}, 3.8 ; \mathrm{S} 8.7 ; \mathrm{G}_{2}, 3.5 ; \mathrm{M}, 0.5$. The generation time $\left(\mathrm{T}_{\mathrm{G}}\right)$ was $16.5 \mathrm{~h}$. Exponentially growing cells were treated with $\mathrm{BrdU}$ at $10^{-5} \mathrm{M}$ for two cell cycles. Colcemid $(0.05 \mu \mathrm{g} / \mathrm{ml})$ was added to the medium for $1.5 \mathrm{~h}$ before harvest. Cells were treated with $0.075 \mathrm{M} \mathrm{KCl}$ for 10 min then fixed with methanol:acetic acid (3:1). Air-dried prep-

Abbreviations used: bred, bredinin; 6-MP, 6-mercaptopurine; Ara-C, 1- $\beta$-D-arabinofuranosylcytosine; 5-FU, 5-fluorouracil; 5-FUdR, 5-fluorodeoxyuridine; BLM, bleomycin; AMD, actinomycin D; PM, puromycin; $\mathrm{CH}$, cycloheximide; MMC, mitomycin C; EMS, ethylmethanesulfonate; BrdU, 5-bromodeoxyuridine; SCEs, sister chromatid exchanges. 
arations were processed with the fluorescent plus Giemsa (FPG) technique of Wolff and Perry (9). More than 50 cells were scored for SCEs after each treatment. The source of agents used in this study was the same as in previous studies $(7,8)$.

\section{RESULTS}

Tables 1 and 2 summarize the effects of individual inhibitors in the presence or absence of EMS after a $16 \mathrm{~h}$ incubation. Nucleic acid antagonists in the absence of EMS profoundly affected the frequency of SCEs, the effect increasing with the concentration of the agent. In contrast inhibitors of protein synthesis, puromycin (PM) and cycloheximide $(\mathrm{CH})$ had no significant effect. Several agents had dramatic effect on the frequency of induced SCEs in the presence of EMS. Bredinin, hydroxyurea (HU) and 5-fluorodeoxyuridine (5-FUdR) acted synergistically whereas PM and $\mathrm{CH}$ acted antagonistically. Other combinations were neither synergistic nor antagonistic.

Table 3 and 4 show the influence of the $S$ phase on the interactions of EMS, FUdR, and $\mathrm{CH}$ tested with various drug combinations at $6.5,9.5$ and $12.5 \mathrm{~h}$ prior to harvest (the late, middle and early $\mathrm{S}$ phase respectively). In each case, chromosome preparations were made after a $3 \mathrm{~h}$-incubation.

In Table 5, cells were treated with $\mathrm{CH}$ for 1,2 or $3 \mathrm{~h}$ followed by incubation with EMS for $12.5 \mathrm{~h}$ prior to harvest. In one case, cells were treated with $\mathrm{CH}$ for $2 \mathrm{~h}$, then after suspension for $2 \mathrm{~h}$ in the basal medium then were incubated with EMS for 12.5 $\mathrm{h}$. The interference effect occured even when treatment was given $1 \mathrm{~h}$ immediately before $\mathrm{S}$. On the other hand, treatment with $\mathrm{CH}$ for $2 \mathrm{~h}$ in the early stage at $\mathrm{G}_{1}$ had no effect on the frequency of EMS-induced SCEs (Table 5).

\section{DISCUSSION}

There are a number of possible explanations for the results in Tables 1 and 2 . Several authors have proposed a relationship between the formation of SCEs and DNA repair $(2,3,4,6,10)$. Since long-lived DNA breaks and gaps induced by EMS would normally be subject to post-replication repair, some of the lesions could serve as the origins of SCEs and chromosome aberrations. In the presence of DNA inhibitors the repair process might be suppressed and recombination favored. Bredinin, HU and FUdR could cause such suppression by depleting DNA precursor pools. Precursor depletion would act primarily at the replicating points and secondarily at the repair sites. One speculation is that a considerable portion of the EMS-induced lesions occur at sites of semiconservative DNA synthesis, so that abnormalities at the replication forks enhance the frequency of EMS-induced SCEs. This explanation is nevertheless inadequate because the other DNA inhibitors listed in Table 1 (for example 6-MP) did not display synergism. Moreover, protein inhibitors such as PM and $\mathrm{CH}$ reduced the frequencies of EMS-induced SCEs. Protein synthesis may therefore play an important role in the production of SCEs.

The influence of the cell cycle phase on interactions between EMS and the inhibitors listed in Tables 1 and 2 was tested with a modification of the procedure described by Benedict et al. (1).

In cells exposed to $10^{-3} \mathrm{M}$ EMS $16 \mathrm{~h}$ prior to harvest and each of the inhibitors $3.5 \mathrm{~h}$ before harvest (corresponding to the $\mathrm{G}_{2}$ phase), additive effects occurred in all 
TABLE 1. EFFECTS OF NUCLEIC ACID SYNTHESIS INHIBITORS AND ANTITUMOR AGENTS ON THE FREQUENCY OF EMS-INDUCED SISTER CHROMATID EXCHANGES IN CHINESE HAMSTER CELLS

\begin{tabular}{|c|c|c|c|c|c|c|}
\hline \multirow{2}{*}{\multicolumn{3}{|c|}{ Treatment }} & \multirow[b]{2}{*}{ (Mol.) } & \multicolumn{3}{|c|}{ SCEs per Cell (Mean \pm S.D.) } \\
\hline & & & & \multirow{2}{*}{$\begin{array}{l}\text { Observed (A) } \\
4.73 \pm 1.12\end{array}$} & \multirow{2}{*}{$\begin{array}{c}\text { Expected (B) } \\
-\end{array}$} & \multirow{2}{*}{$\begin{array}{c}(\mathrm{A} / \mathrm{B}) \times 100 \\
-\end{array}$} \\
\hline $\mathrm{BrdU}$ & $10^{-5}$ & & & & & \\
\hline EMS & $10^{-3}$ & & & $22.92 \pm 4.46$ & - & - \\
\hline & $5 \times 10^{-4}$ & & & $13.84 \pm 2.16$ & - & - \\
\hline & $10^{-4}$ & & & $8.48 \pm 1.76$ & - & - \\
\hline \multirow[t]{8}{*}{ EMS } & $10^{-3}+$ & + bred & $10^{-5}$ & $30.84 \pm 4.57^{\mathrm{a}}(7.13)$ & 25.32 & 121.8 \\
\hline & & & $10^{-6}$ & $22.69 \pm 4.54(5.42)$ & 23.61 & 96.1 \\
\hline & "I & 5-FUdR & $10^{-5}$ & $31.95 \pm 3.39^{\mathrm{a}}(7.48)$ & 25.67 & 124.5 \\
\hline & "I & & $10^{-6}$ & $23.08 \pm 2.62(6.22)$ & 24.41 & 94.6 \\
\hline & "I & Ara-C & $10^{-6}$ & $25.75 \pm 2.99(7.59)$ & 25.78 & 99.9 \\
\hline & " & & $10^{-7}$ & $22.33 \pm 2.85(5.58)$ & 23.77 & 93.9 \\
\hline & " & AMD & $10^{-8}$ & $32.89 \pm 5.03(15.1)$ & 33.28 & 98.8 \\
\hline & " & BLM & $10^{-2}$ & $25.30 \pm 3.57(6.20)$ & 24. 39 & 103.7 \\
\hline \multirow[t]{8}{*}{ EMS } & $5 \times 10^{-4}+$ & $-\mathrm{HU}$ & $5 \times 10^{-5}$ & $22.13 \pm 4.17^{\mathrm{a}}(7.13)$ & 16.24 & 136.3 \\
\hline & & & $10^{-5}$ & $17.85 \pm 2.52(5.84)$ & 14.95 & 119.4 \\
\hline & & 6-MP & $10^{-6}$ & $16.48 \pm 2.49(7.59)$ & 16.70 & 98.7 \\
\hline & & & $10^{-7}$ & $16.52 \pm 2.79(5.65)$ & 14.76 & 111.9 \\
\hline & & 5-FU & $10^{-5}$ & $17.64 \pm 2.68(6.57)$ & 15.68 & 112.5 \\
\hline & & & $10^{-6}$ & $13.92 \pm 2.68(4.60)$ & 13.71 & 101.5 \\
\hline & & MMC & $10^{-7}$ & $52.29 \pm 6.56(41.4)$ & 50.54 & 103.5 \\
\hline & & & $10^{-8}$ & $21.05 \pm 3.62(10.2)$ & 19. 35 & 108.8 \\
\hline
\end{tabular}

TABLE 2. EFFECTS OF PROTEIN SYNTHESIS INHIBITORS ON THE FREQUENCY OF EMS-INDUCED SISTER CHROMATID EXCHANGES IN CHINESE HAMSTER CELLS

\begin{tabular}{|c|c|c|c|c|c|}
\hline \multirow{2}{*}{\multicolumn{2}{|c|}{ Treatment }} & \multirow[b]{2}{*}{ (Mol.) } & \multicolumn{3}{|c|}{ SCEs per Cell (Mean \pm S.D.) } \\
\hline & & & \multirow{2}{*}{$\frac{\text { Observed (A) }}{4.73 \pm 1.12}$} & \multirow{2}{*}{$\frac{\text { Expected (B) }}{-}$} & \multirow{2}{*}{$\frac{(\mathrm{A} / \mathrm{B}) \times 100}{-}$} \\
\hline BrdU & $10^{-5}$ & & & & \\
\hline EMS & $5 \times 10^{-4}$ & & $13.84 \pm 2.16$ & - & - \\
\hline \multirow[t]{4}{*}{ EMS } & $5 \times 10^{-4}+\mathrm{PM}$ & $5 \times 10^{-6}$ & $11.27 \pm 2.19^{\mathrm{b}}(4.92)$ & 14.03 & 80.3 \\
\hline & & $10^{-6}$ & $13.80 \pm 2.55(5.16)$ & 14.27 & 96.7 \\
\hline & $+\mathrm{CH}$ & $10^{-7}$ & $10.24 \pm 1.98^{\mathrm{b}}(6.22)$ & 15.33 & 66.8 \\
\hline & & $10^{-8}$ & $14.46 \pm 2.62(6.28)$ & 15.39 & 93.9 \\
\hline
\end{tabular}

DON D-6 cells were pretreated with $10^{-5} \mathrm{M}$ BrdU for $16 \mathrm{~h}$. The cells then were incubated with various concentrations of inhibitors for $16 \mathrm{~h}$ only or in combination with EMS. Each value in parentheses represents the frequency of SCEs induced by the inhibitor alone. For the combined effect, the expected SCE values were calculated as in Ray et al. (5).

a The observed value, which was significantly higher than the expected one $(P \leq 0.05)$ represents the synergistic effect.

b The significantly lower value represents the antagonistic effect. 
TABLE 3. EFFECTS OF FUdR ON THE FREQUENCY OF EMS-INDUCED SCES AT DIFFERENT TIMES IN THE S PHASE OF THE SECOND REPLICATION CYCLE

\begin{tabular}{|c|c|c|c|}
\hline \multicolumn{3}{|c|}{ Treatment } & \multirow{2}{*}{$\begin{array}{c}\begin{array}{c}\text { SCEs per Cell } \\
\text { (Mean } \pm \text { S.D. }\end{array} \\
5.34 \pm 1.78\end{array}$} \\
\hline BrdU & & & \\
\hline \multirow[t]{3}{*}{ EMS } & early $\mathbf{S}$ & & $12.68 \pm 2.73$ \\
\hline & middle $\mathbf{S}$ & & $12.54 \pm 2.23$ \\
\hline & late $\mathbf{S}$ & & $8.80 \pm 2.11$ \\
\hline \multirow[t]{3}{*}{ FUdR } & early $\mathbf{S}$ & & $6.40 \pm 1.48$ \\
\hline & middle $\mathbf{S}$ & & $6.29 \pm 1.53$ \\
\hline & late $\mathbf{S}$ & & $5.51 \pm 1.38$ \\
\hline \multirow[t]{9}{*}{ EMS } & early $\mathbf{S}+$ FUdR & early $\mathbf{S}$ & $16.14 \pm 2.96^{\mathrm{a}}$ \\
\hline & & middle $\mathbf{S}$ & $12.71 \pm 2.66$ \\
\hline & & late $\mathbf{S}$ & $11.60 \pm 2.42$ \\
\hline & middle $\mathbf{S}+\mathrm{FUdR}$ & early $\mathbf{S}$ & $13.83 \pm 2.57$ \\
\hline & & middle $\mathbf{S}$ & $13.03 \pm 2.42$ \\
\hline & & late $\mathbf{S}$ & $9.46 \pm 2.11$ \\
\hline & + FUdR & early $\mathbf{S}$ & $9.60 \pm 2.35$ \\
\hline & & middle $\mathbf{S}$ & $10.00 \pm 1.99$ \\
\hline & & late $\mathbf{S}$ & $9.41 \pm 1.67$ \\
\hline
\end{tabular}

TABLE 4. EFFECTS OF CH ON THE FREQUENCY OF EMS-INDUCED SCES AT DIFFERENT TIMES IN THE S PHASE OF THE SECOND REPLICATION CYCLE

\begin{tabular}{|c|c|c|c|}
\hline \multicolumn{3}{|c|}{ Treatment } & \multirow{2}{*}{$\begin{array}{c}\begin{array}{c}\text { SCEs per Cell } \\
(\text { Mean } \pm \text { S.D. })\end{array} \\
5.34 \pm 1.78\end{array}$} \\
\hline BrdU & & & \\
\hline \multirow[t]{3}{*}{ EMS } & early S & & $12.68 \pm 2.73$ \\
\hline & middle $\mathbf{S}$ & & $12.54 \pm 2.23$ \\
\hline & late $\mathbf{S}$ & & $8.80 \pm 2.11$ \\
\hline \multirow[t]{3}{*}{$\mathrm{CH}$} & early $\mathbf{S}$ & & $6.06 \pm 1.30$ \\
\hline & middle $\mathbf{S}$ & & $5.77 \pm 1.44$ \\
\hline & late $\mathbf{S}$ & & $6.00 \pm 1.21$ \\
\hline \multirow[t]{9}{*}{ EMS } & early $\mathrm{S}+\mathrm{CH}$ & early $\mathrm{S}$ & $9.86 \pm 1.72^{\mathrm{b}}$ \\
\hline & & middle $\mathbf{S}$ & $9.66 \pm 1.24^{b}$ \\
\hline & & late $\mathbf{S}$ & $12.46 \pm 2.13$ \\
\hline & middle $\mathbf{S}+\mathrm{CH}$ & early $\mathbf{S}$ & $9.80 \pm 1.64^{\mathrm{b}}$ \\
\hline & & middle $\mathbf{S}$ & $9.34 \pm 1.28^{\mathrm{b}}$ \\
\hline & & late $S$ & $11.43 \pm 2.44$ \\
\hline & late $\mathbf{S}$ & early $\mathbf{S}$ & $8.31 \pm 1.53$ \\
\hline & & middle $\mathbf{S}$ & $8.66 \pm 2.29$ \\
\hline & & late $S$ & $8.83 \pm 1.85$ \\
\hline
\end{tabular}

DON D-6 cells were first treated with $10^{-5} \mathrm{M}$ BrdU for $16 \mathrm{~h}$ after which the cells were exposed to $10^{-3} \mathrm{M}$ EMS only or to EMS plus $2 \times 10^{-5} \mathrm{M}$ FUdR or $10^{-7} \mathrm{M} \mathrm{CH} 12.5-9.5 \mathrm{~h}, 9.5-6.5 \mathrm{~h}$, and 6.5$3.5 \mathrm{~h}$ before harvest. Thus cells were treated with these agents at approximately the eariy, middle or late $\mathbf{S}$ phase of the second replication cycle in BrdU.

a synergistic effect, b antagonistic effect 
TABLE 5. EFFeCts OF CH FOLlOWED DURING THE $\mathrm{G}_{1}$ PHASE OF THE SECOND REPLICATION CYCLE ON THE FREQUENCY OF EMS-INDUCED SCES

\begin{tabular}{|c|c|c|c|}
\hline \multicolumn{3}{|c|}{$\underset{\text { (Mol.) }}{\text { Treatment }}$} & \multirow{2}{*}{$\begin{array}{c}\text { SCEs per Cell } \\
(\text { Mean } \pm \text { S.D. }) \\
6.00 \pm 1.29\end{array}$} \\
\hline $\mathrm{BrdU}$ & $10^{-5}$ & & \\
\hline EMS & $10^{-3}$ & & $17.43 \pm 2.97$ \\
\hline $\mathrm{CH}$ & $10^{-6}$ & $2 \mathrm{~h}$ pulse $2 \mathrm{~h}$ chase before $\mathrm{S}$ & $6.23 \pm 1.43$ \\
\hline & & $3 \mathrm{~h}$ pulse before $\mathrm{S}$ & $5.07 \pm 1.36$ \\
\hline & & " & $5.80 \pm 2.11$ \\
\hline & & "/ & $5.80 \pm 1.69$ \\
\hline \multicolumn{4}{|c|}{ EMS plus $\mathrm{CH}$} \\
\hline & & $2 \mathrm{~h}$ pulse $2 \mathrm{~h}$ chase before $\mathrm{S}$ & $17.64 \pm 2.79$ \\
\hline & & $3 \mathrm{~h}$ pulse before $\mathrm{S}$ & $14.04 \pm 3.25^{\mathrm{b}}$ \\
\hline & & $/ 1$ & $14.00 \pm 2.86^{\mathrm{b}}$ \\
\hline & & "I & $15.00 \pm 2.91^{\mathrm{b}}$ \\
\hline
\end{tabular}

DON D-6 cells were first treated with $10^{-5} \mathrm{M}$ BrdU for $16 \mathrm{~h}$, then with $10^{-6} \mathrm{M} \mathrm{CH}$ for 1,2 , or $3 \mathrm{~h}$ before treatment with $10^{-3} \mathrm{M}$ EMS for $12.5 \mathrm{~h}$. In one experiment, cells were treated with $\mathrm{CH}$ for $2 \mathrm{~h}$ then chased $2 \mathrm{~h}$ before treatment with EMS as shown above. Therefore treatment with $\mathrm{CH}$ approximately took place at the $\mathrm{G}_{1}$ phase of the second replication cycle in $\mathrm{BrdU}$.

b antagonistic effect

cases. Interactions during $\mathrm{G}_{2}$ were therefore neither synergistic nor antagonistic; such effects might have occurred with treatment during the $S$ or $G_{1}$ phases.

As shown in Table 3, a synergistic effect between FUdR and EMS occurs only in cells exposed simultaneously to the inhibitor during the early $\mathrm{S}$ phase. Other phase combinations showed no synergsitic action. This indicates that disturbance of replication rather than repair is the important factor in synergism. Indeed, the reduction in SCE frequency when FUdR is administered after EMS clearly indicates that repair is not the factor in synergism.

The characteristic response of $\mathrm{CH}$ was reduce the formation of EMS-induced SCEs (Table 4). Interference occured when $\mathrm{CH}$ was added during or before the middle $\mathrm{S}$ but not during the late $S$ phase. A similar relationship was observed with combinations of EMS and PM (unpublished data).

Treatment with $\mathrm{CH}$ before the $\mathrm{S}$ phase also caused a signicfiant decrease in the frequency of EMS-induced SCEs during the $S$ and $G_{2}$ phases (Table 5). Apparently the protein synthesized during the late $G_{1}$ or early $S$ phase has a role in regulating SCE frequency. Presumably, this protein is not associated with DNA replication. The principal question arising from these studies is what is the specific nature of the role played by protein synthesis in the mechanism of SCE formation.

\section{REFERENCES}

1. Benedict, W.F., N. Harris and M. Karon. Kinetics of 1- $\beta$-D-arabinofuranosylcytosineinduced chromosome breaks. Cancer Res., 30, 2477-2483, 1970

2. Kato, H. Spontaneous and induced sister chromatid exchanges as revealed by BUdR-labeling method. Int. Rev. Cytol., 49, 55-97, 1977

3. Kato, H. Mechanisms for sister chromatid exchanges and their relation to the production of chromosomal aberration. Chromosoma (Berl.) 59, 179-191, 1977 
4. LATT, S.A. Sister chromatid exchanges, indiced of human chromosome damage and repair: Detection by fluorescence and induction by mitomycin C. Proc. Natl. Acad. Sci. U.S.A. 71, 3162-3166, 1974

5. RAY, J.H., L.C.Altenburg and M.M. JaCobS, Effects of sodium selenite and methyl methanesulfonate or $N$-hydroxy-2-acetylaminofluorene co-exposure on sister-chromatid exchange production in human whole blood cultures. Mutat. Res. 57, 359-368, 1978

6. SASAKI, M.S. Sister chromatid exchanges as possible manifestation of different DNA repair processes. Nature, 269, 623-625, 1977

7. Sono, A., K. Matsumoto, K. Hayano and K. Sakaguchi. Sister chromatid exchanges and chromosome aberrations induced by chemical agents in L5178Y cells. Cell Struct. Funct. 3, 249-254, 1978

8. Sono, A. and K. SAKAGUCHI. Induction of sister chromatid exchanges in Chinese hamster cells by antitumor agents and its relation to the chromosome aberration. Cell Struct. Funct. 3, $341-347,1978$

9. Wolff, S. and P. Perry. Differential Giemsa staining of sister chromatids and the study of sister chromatid exchanges without autoradiography. Chromosoma (Berl.), 48, 341-353, 1974

10. Wolff, S., J. Bodycote, G.H. Thomas and J.E. Cleaver. Sister chromatid exchanges in xeroderma pigmentosum cells that are deffective in DNA excision repair or postreplication repair. Genetics, 81, 349-355, 1975

(Received for publication, February 3, 1979) 